Jurnal Pemberdayaan: Publikasi Hasil Pengabdian kepada Masyarakat

Vol. 2, No. 2, Agustus 2018, Hal. 341-346

ISSN: 2088 4559; e-ISSN: XXXX-XXXX

DOI:

\title{
PEMBUDIDAYAAN TANAMAN APOTIK HIDUP GUNA MENINGKATKAN PEREKONOMIAN MASYARAKAT
}

\author{
Amir Hidayatulloh ${ }^{1}$, Diani Mahandika ${ }^{2}$, Yuniantoro $^{3}$, Muhammad Darajatun Mudzakir ${ }^{4}$ \\ ${ }^{1,2,3,4}$ Universitas Ahmad Dahlan, Jalan Kapas Nomor 9, Semaki, Umbulharjo, Yogyakarta \\ Email: amir.hidayatulloh@act.uad.ac.id
}

\begin{abstract}
ABSTRAK
Lahan pedesaan memiliki banyak manfaat. Lahan tersebut dapat dimanfaatkan sebagai lahan apotik hidup atau tanaman obat keluarga (TOGA), sehingga dibutuhkan upaya untuk memanfaatkan lahan pekarangan tersebut secara lebih efektif. Hal inilah yang mendorong pengabdi untuk melakukan pengabdian di Desa Seloharjo, khususnya dusun Dukuh, Nambangan, dan Bobok Tempel. Pemerintah desa Seloharjo sedang gencar menghimbau kepada seluruh masyarakatnya untuk memanfaatkan pekarangan atau perkebunan yang tersedia. Pengabdi melakukan pengabdian bersama mahasiswa KKN. Mahasiswa memberikan pengetahuan kepada warga mengenai memanfaatkan, membudidayakan, serta mengemas obat agar laku di pasaran. Pengabdi memberi pelatihan mengenai cara pemasaran. Hasil pengabdian adalah masyarakat mengetahui cara memanfaatkan, membudidayakan, mengemas, serta memasarkan hasil olahan dari tanaman obat. Hasilnya adalah pembudidayaan tanaman obat tradisonal memberikan manfaat kepada warga. Manfaat tersebut adalah (1) sebagai sarana untuk menyediakan obat herbal bagi warga, (2) sarana untuk memanfaatkan tanaman herbal di pedesaan sebagai bahan baku obat herbal, yang dapat digunakan sebagai cara alternative untuk mensiasati obat kimia yang relative mahal, serta (3) meningkatkan ekonomi masyarakat melalui pemanfaatan budidaya tanaman herbal yang dapat didistribusikan ke pasar, rumah sakit, industri obat dan lain sebagainya.
\end{abstract}

Kata kunci: Lahan Pedesaan, Tanaman Obat Keluarga, Ekonomi Masyarakat

\begin{abstract}
Rural land has many benefits. The land can be used as living pharmacy (TOGA). Thus, efforts are needed to utilize land more effectively. This is what encourages servants to do service in the village of Seloharjo, especially the hamlet of Dukuh, Nambangan, and Bobok Tempel. The Seloharjo village government is aggressively appealing to all its people to make use of available yards or plantations. Servant conducts service with KKN students. Students provide knowledge to residents about utilizing, cultivating, and packing drugs that will sell on the market. Meanwhile, servants provide training on marketing methods. The result of service is that the community knows the cata uses, cultivates, packs, and markets the processed products from ornamental plants. Thus, cultivation of traditional medicinal plants will provide benefits to residents. The benefits are (1) as a means to provide herbal medicine for residents, (2) a means to utilize herbal plants in the countryside as raw material for herbal medicines, which can be used as an alternative way of dealing with relatively expensive chemical drugs, and (3) community economy through the utilization of cultivation of herbal plants that can be distributed to markets, hospitals, drug industries, and so forth.
\end{abstract}

Keywords: Rural Land, Family Medicinal Plants, Community Economy 


\section{PENDAHULUAN}

Desa Seloharjo merupakan salah satu kelurahan yang berada di kecamatan Pundong, Bantul, Daerah Istimewa Yogyakarta. Kelurahan Seloharjo memiliki 1110.555 Ha. Kelurahan Seloharjo digunakan untuk persawahan, peternakan, jasa dan perdagangan. Namun, beberapa lahan belum dimanfaatkan secara optimal. Padahal, lahan pedesaan dapat memiliki banyak manfaat. Manfaat dari lahan pedesaan antara lain dapat digunakan sebagai lahan untuk menanam tanaman apotik hidup atau tanaman obat keluarga (TOGA). Diperlukan adanya upaya untuk memanfaatkan lahan secara efektif.

Tanaman obat dapat dimanfaatkan sebagai dekorasi halaman maupun bahan ramuan alami untuk mengobati berbagi penyakit. Obat tradisional atau herbal biasanya dimanfaatkan oleh masyarakat menengah kebawah. Masyarakat biasanya memanfaatkan obat tradisional atau herbal untuk mencegah, menyembuhkan, memulihkan, serta meningkatkan kesehatan (Herbie, 2015).

Kondisi saat ini, masyarakat di pedesaan belum sepenuhnya memahami bahwa beberapa tanaman di sekitar mereka dapat digunakan sebagai obat yang dapat didistribusikan kepada industri obat-obatan, rumah sakit, maupun dapat dimanfaatkan untuk keperluan keluarga. Pengetahuan untuk memanfaatkan tumbuhan obat masih sebatas warisan budaya bangsa. Pengetahuan untuk memanfaatkan tanaman obat merupakan pengetahuan dan pengalaman yang diwariskan secara turun temurun (Kumalasari, 2006).

Pilihan untuk memanfaatkan lahan pekarangan yang kosong sebagai lahan apotik hidup merupakan langkah yang tepat untuk dilakukan di desa Seloharjo, khususnya dusun Dukuh, Nambangan, dan Bobok Tempel. Hal ini karena pemerintah Seloharjo sedang gencargencarnya menghimbau seluruh masyarakat khususnya dusun Dukuh, Nambangan, dan Bobok Tempel untuk memanfaatkan lahan pekarangan yang kosong. Ketiga dusun tersebut pada umumnya memiliki lahan pekarangan yang luas. Secara umum lahan pekarangan tersebut dapat dimanfaatkan sebagai lahan untuk menanam tanaman obat serta bumbu dapur untuk memenuhi kebutuhan sehari-hari.

Salah satu tanaman herbal di desa Seloharjo yang dapat dimanfaatkan adalah tanaman jahe. Pemanfaatan tersebut dapat dilakukan secara langsung maupun dalam bentuk kemasan instan, seperti yang telah beredar di pasar. Dengan adanya kemasan tersebut, masyarakat di desa Seloharjo dapat mempraktikan atau membuat kemasan mirip dengan kemasan yang sudah ada. Sehingga, dengan kemasan tersebut dapat menambah nilai ekonomis dari tanaman jahe tersebut, dan secara tidak langsung dapat meningkatkan penghasilan masyarakat setempat. 
Dari uraian sebelumnya, maka tujuan dari pengabdian ini adalah memberikan pengetahuan kepada masyarakat mengenai cara untuk membudidayakan tanaman obat, dan cara memasarkannya. Diharapkan pengabdian ini secara tidak langsung dapat meningkatkan perekonomian masyarakat.

\section{METODE}

Pengabdian ini dilaksakan bulan Febuari 2017 selama 1 bulan yang bertempat di desa Seloharjo, khususnya di dusun Dukuh, Nambangan, dan Bobok Tempel. Pengabdian ini dilakukan oleh mahasiswa KKN Tahun Akademik 2016/2017, berkolaborasi dengan dosen pembimbing lapangan.

Mahasiswa KKN memberikan gambaran mengenai cara membudidayakan tanaman obat yang ada di lahan pekarangan, serta memberikan pelatihan mengenai cara pengemasan. Dosen pembimbing lapangan memberikan pelatihan mengenai cara pemasaran produk.Tahapan pengabdian yang dilakukan oleh mahasiswa KKN UAD dan pengabdi tersaji pada Gambar 1.

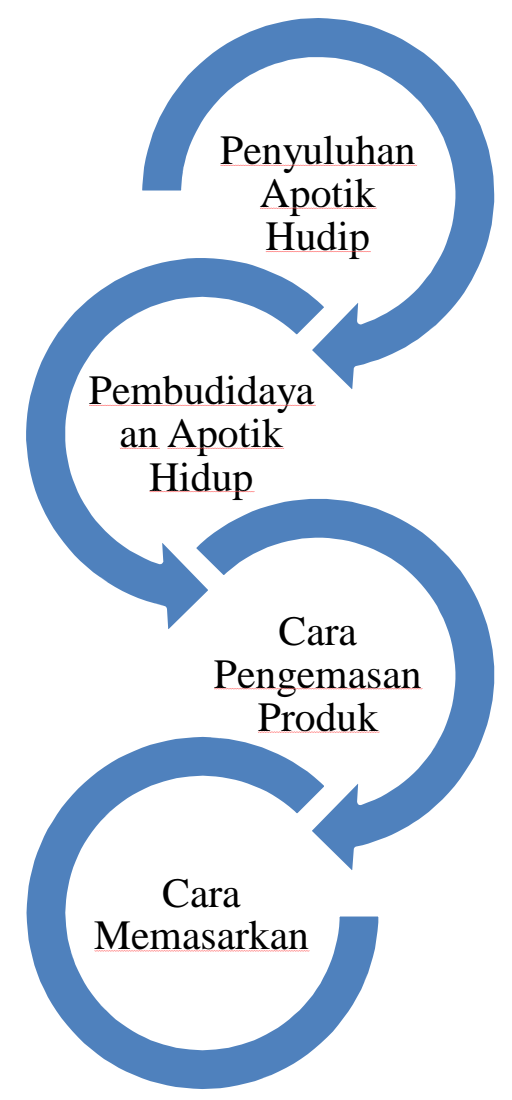

Gambar 1. Tahapan Pengabdian 


\section{HASIL, PEMBAHASAN, DAN DAMPAK}

Pemberdayaan masyarakat di desa Seloharjo, khususnya dusun Dukuh, Nambangan, dan Bobok Tempel memberikan keterampilan kepada masyarakat mengenai manfaat dan kegunaan dari tanaman yang ada di lahan pekarangan, khususnya tanaman jahe. Tanaman jahe dapat dikembangkan menjadi obat tradisonal bagi warga. Kegunaan utama penanaman tanaman obat tersebut adalah untuk memenuhi kebutuhan masyarakat sekitar mengenai kesehatan. Tanaman obat yang ditanam oleh mahasisswa KKN yang berlokasi di dusun Dukuh, Nambangan, dan Bobok tempel tersaji pada tabel 1.

Tabel 1. Jenis tanaman obat yang telah ditanam

\begin{tabular}{|c|c|c|}
\hline No. & Jenis Tanaman & Manfaat \\
\hline 1. & Kunyi & $\begin{array}{l}\text { Menghentikan pendarahan, obat gatal, radang umbai usus buntu, } \\
\text { radang rahim, keputihan, Obat sakit perut dan gangguan liver } \\
\text { Rimpang. }\end{array}$ \\
\hline 2. & Kencur & $\begin{array}{l}\text { Obat Batuk, infeksi bakteri, disentri, selera makan, tonikum, masuk } \\
\text { angin, sakit perut, obat asma dan anti jamur }\end{array}$ \\
\hline 3. & Jahe & mengatasi nyeri pada tulang (adanya bahan aktif dari ekstrak). \\
\hline 4. & Serai & $\begin{array}{l}\text { Mencegah penyakit kanker, mengobati gangguan pencernaan, } \\
\text { menurunkan tekanan darah, manfaat pada sistem saraf }\end{array}$ \\
\hline 5. & Lengkuas & $\begin{array}{l}\text { Mencegah dan Mengobati Tumor, Menyembuhkan Penyakit Limfa, } \\
\text { Mangobati Penyakit Reumatik, Mencagah Radang, Mengurangi } \\
\text { Pusing pada saat mabuk laut, Mengobati diare serta luka dalam } \\
\text { perut, Penambah Nafsu Makan, Mengobati Penyakit Kulit. }\end{array}$ \\
\hline 6. & Jahe Emprit & $\begin{array}{l}\text { Bahan pembuatan jamu segar maupun kering. Jahe emprit juga } \\
\text { digunakan untuk bahan pembuatan minuman, penyedap makanan, } \\
\text { rempah-rempah serta cocok untuk ramuan obat-obatan. }\end{array}$ \\
\hline 7. & Jahe Gajah & $\begin{array}{l}\text { Digunakan untuk sayur, masakan, minuman, permen dan rempah- } \\
\text { rempah. Jahe gajah cocok dikonsumsi waktu berumur muda } \\
\text { maupun tua, baik sebagai jahe segar maupun olahan. }\end{array}$ \\
\hline 8. & Temulawak & $\begin{array}{l}\text { Mengobati sakit kuning, diare, maag, perut kembung, pegal-pegal, } \\
\text { menurunkan lemak darah, mencegah penggumpalan darah dan } \\
\text { memelihara kesehatan tubuh. }\end{array}$ \\
\hline 9. & Sambiloto & $\begin{array}{l}\text { Melindungi hati, sambiloto juga dapat menekan pertumbuhan sel } \\
\text { kanker. }\end{array}$ \\
\hline 10. & Merica & Membantu menurunkan berat badan. \\
\hline 11. & Bayam Merah & $\begin{array}{l}\text { Membersihkan darah sehabis bersalin, anemia, meningkatkan kerja } \\
\text { ginjal, menurunkan resiko terserang kanker, sebagai antidiabetes, } \\
\text { memperbaiki sistem pencernaan, mengurangi kolesterol, dan } \\
\text { memperkuat akar rambut }\end{array}$ \\
\hline
\end{tabular}

Sumber: Widyawati dan Rizal (2015). 
Tabel 1 menunjukkan data bahwa tanaman obat yang dibudidayakan sudah bervariasi. Akan tetapi, tanaman jenis jahe-jahean mendominasi tanaman obat yang dibudidayakan, misal jahe merah, sambiloto, rumput mutiara, soka, alang-alang dan sirih. Tanaman obat keluarga (TOGA) dapat dijadikan peluang masyarakat untuk berwiarausaha. Hal ini dapat dilakukan dengan memanfaatkan tanah yang kosong di sekitar rumah untuk menanam atau membudidayakan tanaman obat keluarga. Adanya ide kreatif dan inovatif dari masyarakat untuk mengembangkan olahan dari tanaman obat keluarga menjadi racikan obat-obatan yang bervariasi, seperti makanan dan minuman sehat. Kemampuan inovatif dan kreatif merupakan dasar, kiat, dan sumber daya untuk mencari peluang menuju kesuksesan (Suryana, 2006).

Penanaman apotik hidup memiliki dampak positif dari sisi ekonomis. Dampak positif tersebut meliputi (1) budidaya tanaman apotik hidup (toga) dapat meningkatkan jumlah masyarakat untuk berwirausaha, khususnya berwirausaha pada bidang obat-obatan herbal. Sehingga, kegiatan budidaya tanaman hidup secara tidak langsung mendorong kemandirian masyarakat, baik dalam sisi keuangan maupun pengobatan, (2) mengurangi efek ketergantungan masyarakat pada penggunaan obat kimia.

\section{SIMPULAN}

Pembudidayaan tanaman obat tradisional dengan memanfaatkan lahan pekarangan untuk tanaman obat memiliki beberapa manfaat, antara lain (1) sarana untuk menyediakan obat herbal bagi warga, (2) sarana untuk memanfaatkan tanaman herbal di pedesaan sebagai bahan baku obat herbal sebagai cara alternatif menanggulangi obat kimia yang harganya relatif mahal. Serta (3) meningkatkan ekonomi masyarakat melalui pemanfaatan budidaya tanaman herbal yang dapat didistribusikan ke pasar, rumah sakit, industry obat, dan lain sebagainya.

\section{DAFTAR PUSTAKA}

Herbie, Tandi. (2015). Kitab Tanaman Berkhasiat Obat 226 Tumbuhan Obat untuk Penyembuhan Penyakit dan Kebugaran Tubuh. Yogyakarta: OCTOPUS Publishing House.

Kumalasari, L.O.R. (2006). Pemanfaatan Obat Tradisional dengan Pertimbangan Manfaat dan Keamanannya. Majalah Ilmu Kefarmasian, Volume 111, Nomor 1, Halaman:1-7.

Suryana. (2006). Kewirausahaan Pedoman Praktis: Kiat dan Proses Menuju Sukses (Edisi III). Jakarta: Salemba 
Widya, Tri Widyawati, dan Rizal, Muhammad. (2015). Upaya Pemberdayaan Apotik Hidup di Perkotaan Melalui Deskripsi dan Manfaat Tanaman Obat. Pros Sem Nas Masy Biodiv Indon, Volume 1, Nomor 8, Halaman: 1890-1895

\section{UCAPAN TERIMAKASIH}

Saya ucapkan terima kasih kepada Mahasiswa KKN Periode LXI Tahun Akademik 2016/2017, Khususnya mahasiswa yang KKN di Dusun Dukuh, Nambangan, dan Bobok Tempel Desa Seloharjo. Pengabdi juga ucapkan terima kasih kepada Lembaga Penelitian dan Pengabdian Masyarata Universitas Ahmad Dahlan yang selalu mendukung pengabdi untuk melakukan pengabdian. Terima kasih pengabdi ucapkan juga kepada pemerintah desa Seloharjo dan Warga desa Seloharjo atas kerjasama selama ini. 